\title{
VACANT REFORM: WHY THE FEDERAL VACANCIES REFORM ACT OF 1998 IS UNCONSTITUTIONAL
}

\author{
JOSHUA L. STAYN
}

\section{INTRODUCTION}

The way executive branch officials are nominated and confirmed these days seems to please none of the people, none of the time. Presidential supporters contend that senators are so ideologically charged and so concerned with reelection that they block presidential nominations "for reasons that have nothing to do with the nominee, and everything to do with some unrelated dispute between president and Senate." Congressional supporters counter that the real problem is that presidents are so obsessed with their public opinion ratings and legacy that they misuse their nomination and appointment powers to curry favor with special interest groups and to push the nation in impolitic directions. ${ }^{2}$ And those who, favoring neither branch, merely want a healthy democracy fear that the federal appointment process recently has strayed too far from its constitutional roots. ${ }^{3}$ In an effort

Copyright $@ 2001$ by Joshua L. Stayn.

1. A Tyrannous Minority, THE ECONOMIST, Jan. 10, 1998, at 24.

2. James C. Ho, A Year of Bill Lann Lee, WASH. TIMES, Dec. 24, 1998, at A17; James C. Ho, Don't Consent to Bill Lann Lee, WASH. TIMES, Mar. 9, 1999, at A17; see also David M. O'Brien, Background Paper, in TASk Force on Judicial SElection, Twentieth Century Fund, Judicial Roulette: REPORT OF THE TwENTIETH CENTURY Fund TASK ForCE ON JUDICIAL SELECTION 13, 21, 24 (1988) (criticizing President Ronald Reagan for attempting, as his own Attorney General Edwin Meese admitted, to "institutionalize the Reagan revolution so it can't be set aside no matter what happens in future presidential elections" by administering an ideological "litmus test" to potential judicial nominees); Jeffery H. Birnbaum, Clinton's Choices for Cabinet Posts Give Few Clues About His Plans for Change, WALl St. J., Dec. 28, 1992, at A3 (criticizing President-elect Bill Clinton for nominating four blacks, two Hispanics, and three women to his initial cabinet based on little more than political symbolism, interest-group pressure, and cronyism).

3. See generally Obstacle Course: The Report of The Twentieth Century Fund TAsk Force on The Presidential Appointment Process vi, 1, 4-8 (1996) [hereinafter OBSTACLE COURSE] (concluding that the average confirmation time for a presidential appointee has more than quadrupled since the Kennedy administration, the appointment process 
to stop the perceived perversions of that process, a Republican-led Congress enacted, and Democratic President Bill Clinton signed into law, the Federal Vacancies Reform Act of $1998 .{ }^{4}$

The Federal Vacancies Reform Act of 1998 completely rewrites the law governing federal vacancies and employs new enforcement mechanisms in an effort to ensure that the President respects the Senate's advice and consent role when appointing executive branch officers. ${ }^{5}$ The Act states that it is the sole statutory vehicle for temporarily filling vacant positions pending confirmation, and it enumerates the exclusive ways in which a President may make such temporary appointments. ${ }^{6}$ It provides incentives for prompt submission of nomi-

has become more contentious and uncivil, and the American public has become more distrustful of and alienated from the political system).

4. 5 U.S.C. $\$ \S 3345-3349 d$ (Supp. V 1999). In urging passage of the Act, co-sponsor Senator Robert Byrd (D-WV) admonished fellow senators that:

[E]ach time a vacancy is filled by an individual in violation of the Vacancies Act, yet another pebble is washed off the riverbank of the Senate's constitutional role . . . as more and more of these pebbles tumble downstream, the bank weakens, until, finally, it collapses.... [W] ] have a responsibility to the American people and to ... the Senate ... to shore up that riverbank, to stop the erosion that has taken place, and to reverse the wretched trend of acquiescing on our constitutional duties that seems to have so ominously infected this Senate.

144 CONG. REC. S11021-01, S11025 (Sept. 28, 1998) (statement of Sen. Byrd).

5. Executive branch officers, also called "Officers of the United States," are individuals appointed by the President, a court, or agency head, who exercise "significant authority" under a federal statute in carrying out the "continuing and permanent" duties of the "public station, or employment" which they hold. Buckley v. Valeo, 424 U.S. 1, 126 (1976) (holding that Article II, Section 2, Clause 2 of the Constitution requires that most of the powers that the Federal Election Campaign Act of 1971 confers upon the Federal Election Commission be exercised only by "Officers of the United States," and that, as a result, the membership of the Federal Election Commission was invalid); United States v. Mouat, 124 U.S. 303, 307 (1888) (holding that unless a person holds a government position by virtue of appointment by the President, the courts, or a department head legally authorized to make the appointment, that person is not an "officer" of the United States); United States v. Hartwell, 73 U.S. (6 Wall.) 385, 398 (1868) (reasoning that the defendant, a clerk in an assistant U.S. treasurer's office, was a public officer for the purpose of the Sub-Treasury Act of 1846, which forbade public officials from misappropriating public funds, but holding that the statute did not apply because the defendant's office was not listed in the statute). As of 1992, there were 1520 full-time and part-time executive branch positions requiring presidential appointment and Senate confirmation. G. Calvin Mackenzie, The Presidential Appointment Process: Historical Development, Contemporary Operations, Current Issues, in OBSTACLE COURSE, supra note 3 , at 35, 43.

6. Three categories of temporary appointments exist: (1) those made under Article II, Section 2, Clause 3 of the Constitution during a Senate recess and lasting until the end of the Senate's next session; (2) those made under statutory authority and subject to a prescribed time limitation, see infra notes 17-22, 52, and accompanying text; and (3) those deemed "temporary" by the President to avoid the confirmation requirement for permanent appointments and any time limit not set by the President. Lois Reznick, Note, Temporary Appointment Power of the 
nations and punishes statutory noncompliance. The Act also assigns to executive agency heads and to the Comptroller General responsibility for monitoring compliance with the Act and makes special provisions for vacancies that result from a change of administration following a presidential election. ${ }^{7}$ Despite the likelihood that these revisions will fundamentally alter the federal appointment process, few supporters or critics of the current process have analyzed the constitutionality of the Act. ${ }^{8}$

This Note undertakes such an analysis and concludes that the Federal Vacancies Reform Act of 1998 is unconstitutional. The Act violates Article II by allowing the Senate unilaterally to nominate and confirm or reject individuals whom the President has not actually nominated; by interfering with the President's exercise of his exclusive constitutional power to make recess appointments; by facilitating congressional encroachment on the President's long-recognized prerogative to nominate and control subordinate executive officers; and by tilting the balance of appointment power dangerously toward a new President during his first year in office.

Part I of this Note outlines the events leading to the passage of the Federal Vacancies Reform Act of 1998. Part II summarizes each section of the Act and its intended function. Part III presents four arguments against the constitutionality of the Act. Part IV concludes that the Act should be repealed or substantially amended to cure its constitutional defects, and suggests modifications that, if adopted, might enable the Act constitutionally to meet the needs and objectives of both the Senate and the President.

President, 41 U. CHI. L. REV. 146, 147 n.9 (1973) (examining the language, history, and executive and judicial interpretations of the Appointments Clause).

7. 5 U.S.C. $\S \S 3349,3349$ a (Supp. V 1999).

8. But see Michael J. Gerhardt, The Federal Appointments Process: A CONSTITUTIONAL AND HistoricAl ANALYSIS 270-72, 379 n.29 (2000) (“[T]he new statute's effort to cover all temporary appointments to confirmable positions is constitutional. First, the Constitution plainly empowers Congress to create and fund offices.... [T] his congressional power has been granted without any explicit limitations; therefore, it presumably encompasses the authority to establish the conditions for occupancy ...."); Morton Rosenberg, Congress Reforms Vacancies Act to Protect the Senate's Confirmation Prerogative, ADMIN. L. \& REG. NEWS, Spring 1999, at 1-6 (arguing that a reviewing court would likely find that "the Act is the exclusive vehicle for temporarily filling vacant advice and consent positions unless Congress expressly provides otherwise.”). 


\section{BACKGROUND}

\section{A. The Framers' Intent: Presidential Appointment Power}

The allocation of the appointment power between the President and Congress has evolved differently than the Framers intended. The Framers' competing views on the proper allocation of that power have been thoroughly documented elsewhere. ${ }^{9}$ Nonetheless, it is worth emphasizing that the Framers intended to make the President alone constitutionally responsible for nominating and temporarily appointing federal officers and to make the Senate responsible for checking those powers. ${ }^{10}$ The Framers made those intentions clear in both the text and structure of the Appointments Clause. That Clause provides:

9. E.g., Joseph P. Harris, The Advice and Consent of the Senate 17-19 (1968) ("One group ... [was] afraid of granting the appointing power to the executive ... and believed that the power would be more safely entrusted to the upper branch of the legislature.... Another group ... favored the creation of a strong executive, who they believed would be better qualified ... than a numerous body."); Jeffrey K. Tulis, Constitutional Abdication: The Senate, the President, and Appointments to the Supreme Court, 47 CASE W. RES. L. REV. 1331, 1339-42 (1997) (summarizing the views of individual members of the Constitutional Convention concerning the proper role of the President and Senate in making appointments); Christopher Wolfe, The Senate's Power to Give "Advice and Consent" in Judicial Appointments, 82 MARQ. L. REV. 355, 357 (1999) ("Some delegates, then, were concerned that a president might use appointment to draw too much power to himself. Still, some of the delegates were concerned that the Senate's power to advise and consent would not amount to much.”); Stuart J. Chanen, Note, Constitutional Restrictions on the President's Power to Make Recess Appointments, 79 Nw. U. L. REV. 191, 195 n.28 (1984) ("Some of the Framers argued that the executive should have the whole appointment power, without restraint or qualification, in order to establish a strong national government. Others opposed vesting the uncontrolled power of appointment in a single executive, fearing it would lead toward monarchy."); Note, Power of Appointment to Public Office Under the Federal Constitution, 42 HARV. L. REV. 426, 428 (1929) ("The members of the Convention were experienced in the practical administration of government. ... They therefore must have thought it best to permit the necessities and conveniences of government ... to allocate the power of appointment to that agency which could exercise it most efficiently.").

10. Thomas Jefferson, Jefferson's Opinion on the Powers of the Senate Respecting Diplomatic Appointments, in 16 THE PAPERs OF ThOMAs JeFFERSON 378, 379 (Julian P. Boyd ed., 1961) (1790) (stating that the Appointments Clause gives the Senate no independent power because the Constitution "gives the nomination ... to the President, the appointment to him and the Senate jointly, the commissioning to the President"); Peter M. SHAne \& Harold H. Bruff, Separation of Powers Law: CASES AND Materials 383 (1996) (arguing that the clear difference between a draft version of the Constitution that vested appointment authority in the Senate and the finally adopted version of Article II indicates that the Framers intended to deny Congress any authority to appoint "Officers of the United States"); Charles L. Black, Jr., A Note on Senatorial Consideration of Supreme Court Nominees, 79 YALE L.J. 657, 659 n.3 (1970) (arguing that the Senate's consent is advisory because confirmation does not bind the President to commission the confirmed nominee). 
[The President] shall nominate, and by and with the Advice and Consent of the Senate, shall appoint Ambassadors, other public Ministers and Consuls, Judges of the supreme Court, and all other Officers of the United States, whose Appointments are not herein otherwise provided for, and which shall be established by law ....

The President shall have Power to fill up all Vacancies that may happen during the Recess of the Senate, by granting Commissions which shall expire at the End of their next session. ${ }^{11}$

Furthermore, the Clause is structured to give the President a significant advantage in obtaining the confirmation of nominees. The Clause makes it difficult for the Senate to reject a nominee absent compelling reasons by authorizing the President to make repeated nominations, placing the nomination and appointment powers in a unitary branch, and formulating the Senate's confirmation power as a defensive veto. ${ }^{12}$ The Framers concentrated the nomination and temporary appointment powers in the President to assure undivided accountability for the initial choice of an appointee and to avoid the "[i]ntrigue, partiality, and concealment" likely to arise in the selection of appointees by a multimember body such as the Senate. ${ }^{13}$ As Alexander Hamilton explained:

The sole and undivided responsibility of one man will naturally beget a livelier sense of duty and a more exact regard to reputation. $\mathrm{He}$ will, on this account, feel himself under stronger obligations, and more interested to investigate with care the qualities requisite to the stations to be filled, and to prefer with impartiality the persons who may have the fairest pretensions to them. He will have fewer per-

11. U.S. CONST. art. II, $\S 2$, cl. 3 (emphasis added). Indeed, initially the delegates to the Constitutional Convention voted to give unilateral power to the President "to appoint to offices in cases not otherwise provided for" in the Constitution. LOUIS Fisher, Constitutional CONFLICTS BETWEEN CONGRESS AND THE PRESIDENT 23 (4th ed. rev. 1997).

12. John O. McGinnis, Essay, The President, the Senate, the Constitution, and the Confirmation Process: A Reply to Professors Strauss and Sunstein, 71 TEX. L. REV. 633, 653-59 (1993) (arguing that the structure of the Appointments Clause puts the political burden of proof on the Senate to justify its rejection of a nominee by offering serious, publicly compelling reasons).

13. FISHER, supra note 11, at 23 (quoting Constitutional Convention delegate James Wilson); see also 2 THE RECORdS OF THE FEDERAL CONVENTION OF 1787, at 42 (Max Farrand ed., 1966) (remarks of Nathaniel Gorham) (arguing that lodging the appointment power in the Senate would "give full play to intrigue \& cabal") [hereinafter RECORDS OF THE FEDERAL COnVEntion]. See generally James E. Gauch, Comment, The Intended Role of the Senate in Supreme Court Appointments, 56 U. CHI. L. REV. 337, 343-46 (1989) (citing the comments of several delegates to the Convention warning that corruption and intrigue would result from vesting the nomination or appointment powers in a diffuse, multimember body). 
sonal attachments to gratify than a body of men who may each be supposed to have an equal number; and will be so much the less liable to be misled by the sentiments of friendship and of affection. ${ }^{14}$

The Framers' concerns, as articulated by Hamilton, have been echoed periodically by all three branches of the federal government. ${ }^{15}$

\section{B. Congress's Efforts to Control Executive Branch Appointments}

Although the Framers intended to empower the President alone to nominate and temporarily appoint federal officers, the Framers vested the power of advice and consent regarding nominees and appointees in the Senate in order to avoid the "incautious or corrupt nominations" and "flagrant partiality or error" otherwise likely to result from presidential misuse of the appointment power. ${ }^{16}$ At least since 1795, several Congresses have asserted that the Senate has some discretion to limit the President's choice of nominees and temporary appointees, as well as their tenure in office. ${ }^{17}$ A common means by which Congresses have done so is vacancies legislation. ${ }^{18}$ Enacted in 1868, the first Vacancies Act purported to restrict the President's temporary appointment options by requiring that a temporary or recess appointee be either the first assistant to the vacant office or an already confirmed federal officer. ${ }^{19}$ The 1868 Act also limited the chosen appointee's tenure to ten days. ${ }^{20}$ Subsequent Congresses have fur-

14. The FedERAlist No. 76, at 455-56 (Alexander Hamilton) (Clinton Rossiter ed., 1961).

15. E.g., Pub. Citizen v. United States Dep’t of Justice, 491 U.S. 440, 483 n.4 (1989) (Kennedy, J., concurring) (quoting, with approval, Hamilton's statement shown above); Marbury v. Madison, 5 U.S. (1 Cranch) 137, 155 (1803) (calling the nomination process the "sole act of the president" and "completely voluntary"); see also 1 DEBATES AND PROCEEDINGS IN THE CONGRESS OF THE UNITED STATES 561 (Joseph Gales ed., 1834) (reporting Congressman Fisher Ames's statement that the Senate, though it must evaluate a candidate, cannot nominate one); 7 Op. Att'y Gen. 187, 223 (1855) (stating that "howsoever a vacancy happens to exist, if it exists, it may be filled by temporary appointment of the President"); Senator Charles McC. Mathias, Jr., Advice and Consent: The Role of the United States Senate in the Judicial Selection Process, 54 U. CHI. L. REV. 200, 202 (1987) (stating that "[c]ertainly, as Hamilton argues, the power to nominate is the president's alone").

16. ReCORdS OF THE FEDERAL CONVENTION, supra note 13, at 80 (remarks of James Madison).

17. The third Congress was the first to limit the pool and tenure of presidential nominees or temporary appointees; it limited temporary assignees' tenure in office to six months. Act of Feb. 13, 1795, ch. 21, 1 Stat. 415.

18. FISHER, supra note 11, at 39-43 (discussing Congress's periodic efforts to impose statutory restrictions on the President's power to fill vacant advice and consent positions).

19. Act of July 23,1868 , ch. 227,15 Stat. 168.

20. Id. 
ther amended that Act, ${ }^{21}$ forbidding the payment of salary to recess appointees until the Senate confirms their appointment and requiring that the President promptly submit nominations for vacant positions after filling them with recess appointees. ${ }^{22}$ Some Congresses have even defunded officer positions, set eligibility criteria, and threatened to reject undesired nominees if the President did not withdraw their names. ${ }^{23}$

Presidents from 1823 through 1879 used the Appointments Clause, without Congress's permission, to fill vacancies that arose while the Senate was in session and to make successive recess appointments. ${ }^{24}$ Yet, almost all presidents from 1880 through 1972 appear to have respected Congress's disapproval both of successive recess appointments of the same or another officer to a vacant office and of recess appointments to vacancies that did not occur during a Senate recess. ${ }^{25}$

21. E.g., Act of Feb. 6, 1891, ch. 113, 26 Stat. 733 (extending the temporary appointee's tenure to thirty days); Pub. L. No. 100-398, 102 Stat. 988 (1988), codified at 5 U.S.C. $§ 3348$, amended by Federal Vacancies Reform Act of 1998, 5 U.S.C. $§ 3346$ (1998) (extending the temporary appointee's tenure to 120 days). Under the statute in its present form, the appointee's tenure lasts until a successor is appointed or the absence or sickness ends. 5 U.S.C. $\S 3346$ (Supp. V 1999).

22. Treasury and General Government Appropriations Act for Fiscal Year 1998, Pub. L. No. 105-61, § 610, 111 Stat. 1272, 1310 (1997) (barring payment to any person who fills an advice and consent position for which he or she has already been nominated and rejected); 5 U.S.C. $\S$ 5503 (1994) (forbidding payment, except in enumerated circumstances, to unconfirmed recess appointees who fill vacancies that existed while the Senate was in session); Tenure in Office Act, ch. 154, 14 Stat. 430, 431 (1867) (requiring that vacant or temporarily filled advice and consent positions "remain in abeyance, without any salary, fees, or emoluments" if the President does not promptly fill them with Senate-confirmed nominees during the next Senate session).

23. FISHER, supra note 11 , at $26,32-33,43$.

24. The presidents relied upon the opinions of their attorneys general, which at least one circuit court has approved as precedent in the appointments context. United States v. Allocco, 305 F.2d 704, 713 (2d Cir. 1962) ("Our decision is not without precedent. The AttorneysGeneral of the United States... have held in a long and continuous line of opinions that the recess power extends to vacancies which arise while the Senate is in session."); 12 Op. Att'y Gen. 32, 39 (1866); 10 Op. Att'y Gen. 356, 356 (1862); 7 Op. Att'y Gen. 186, $225-26$ (1855); 4 Op. Att'y Gen. 523, 526 (1846); 2 Op. Att'y Gen. 525, 530 (1832); 1 Op. Att'y Gen. 631, 633 (1823).

25. 32 Op. Att'y Gen. 139, 141 (1920); 20 Op. Att'y Gen. 8, 9 (1891); 18 Op. Att'y Gen. 58, 59 (1884); 17 Op. Att'y Gen. 530, 531 (1883); 16 Op. Att'y Gen. 596, 597 (1880). But see, e.g., 23 Op. Att'y Gen. 599, 603 (1901) (Mr. Knox) ("If a temporary appointment could in this case be legally made during the current adjournment as a recess appointment, I see no reason why such an appointment should not be made during any adjournment, as from Thursday or Friday until the following Monday."). 


\section{The President's Reassertion of the Appointment Power}

In 1973, President Richard Nixon asserted that the Vacancies Act was only one possible means of temporarily filling advice and consent positions and that the enabling statutes of some departments and agencies, including the Justice Department, were equally legitimate means of temporarily filling such positions. ${ }^{26}$ Specifically, the Nixon Justice Department claimed that 28 U.S.C. $\S 509$ and $\S 510$ permitted the Attorney General "from time to time to make such provisions as he considers appropriate authorizing the performance by any other officer, employee, or agency of the Department of Justice of any function of the Attorney General." 27 The Justice Department also claimed that these "vesting and delegation" provisions, which date from the Department's establishment in 1870, made the time limitations in the Vacancies Act inapplicable to vacant positions in any department. ${ }^{28}$

The refusal of the Nixon administration and subsequent presidential administrations to comply with the Vacancies Act resulted in a significant number of temporary appointees serving in violation of Congress's asserted limits and without the Senate's advice and consent. At the Justice Department alone, at least forty-eight people between 1981 and 1998 served as temporary appointees in advice and consent positions for longer than the 120 days authorized by the Vacancies Act in effect during that time. ${ }^{29}$ And by February 28, 1998, sixty-four of the 320 total advice and consent posts in the Clinton administration $(20 \%)$ were held by "acting" officials, forty-three of whom had served more than the 120-day limit without a nomination being submitted. ${ }^{30}$

\section{Interbranch Conflict and the Emergence of the New Vacancies Act}

The conflict between the President and the Senate over presidential noncompliance with the Vacancies Act came to a head in late 1997. Five months after Democratic President Bill Clinton nominated prominent civil rights lawyer Bill Lann Lee to head the Justice De-

26. Morton Rosenberg, The New Vacancies Act: Congress Acts to Protect the Senate's Confirmation Prerogative, CRS REPT. 98-892A, Nov. 2, 1998, at 2-3.

27. Id. at 3 .

28. Id.

29. Id. at 4 .

30. Id. 
partment's Office of Civil Rights, ${ }^{31}$ the Republican-controlled Senate Judiciary Committee refused to refer Lee for a Senate vote because of concerns about his views on race-based preferences and affirmative action. $^{32}$ President Clinton briefly considered waiting until the Senate adjourned for the winter holidays and then exercising his recess appointment power under Article II to appoint Lee for a year. ${ }^{33}$ When Senate leaders threatened to retaliate if the President carried out this constitutionally authorized end run around the confirmation process, ${ }^{34}$ President Clinton appointed Lee "acting" Assistant Attorney General for Civil Rights.

In response to the appointment, Senate Judiciary Committee Chairman Orrin Hatch wrote a letter to Attorney General Janet Reno in which he argued that the Vacancies Act limited Lee's service as an acting executive branch official to 120 days. ${ }^{36}$ Although the letter and the Act attracted media attention, many dismissed the Act as "burdensome," "obscure," and "routinely ignore[d].", In both testi-

31. Naftali Bendavid, Clinton Picks a Civil Rights Chief, CHI. TRIB., June 13, 1997, at 4. For background information on Lee and his nomination, see Roberto Suro, Civil Rights Nominee Has Made Allies of Adversaries; Solution-Oriented Lee Faces Scrutiny in Senate, WASH. Post, Aug. 20, 1997, at A23 (discussing Lee's career as a civil rights lawyer prior to his nomination).

32. Brannon P. Denning, Article II, the Vacancies Act and the Appointment of "Acting" Executive Branch Officials, 76 WASH. U. L.Q. 1039, 1039 (1998). The eighteen-member Senate Committee on the Judiciary deadlocked 9-9 along party lines except for Senator Arlen Specter (R-PA), who supported Lee's nomination. Nancy E. Roman, Senate Panel Spikes Justice Nomination; Ships Lee's Name Back to White House, WASH. TIMES, Nov. 14, 1997, at A1.

33. Jackie Calmes, Hatch Suggests Means of Filling Civil-Rights Job, WALL ST. J., Dec. 15, 1997, at A6.

34. Jonathan Peterson, Putting Lee in Rights Post Seen As Risky Clinton Move, L.A. TiMES, Dec. 15, 1997, at A1 ("Senate Republicans have warned that if Clinton makes a recess appointment, they are prepared to retaliate on other White House nominees, program funding and Democratic legislation."). But cf. Chanen, supra note 9, at $201 \mathrm{n} .67$ (observing that the Senate, though able to express its disapproval of presidential recess appointments by refusing to confirm recess appointees whose names later are submitted for permanent appointment, cannot legally stop the President from making such appointments).

35. William Neikirk \& Naftali Bendavid, Clinton Flanks GOP, Names Lee to Post; Civil Rights Advocate to Be "Acting” Chief, CHI. TRIB., Dec. 16, 1997, at 6; Warren P. Strobel \& Nancy Roman, Lee Named Acting Rights Chief; Clinton's Move Aimed at Cutting GOP Retaliation, WASH. TIMES, Dec. 16, 1997, at A1.

36. Letter from Orrin G. Hatch, Chairman, Senate Judiciary Committee, to Janet Reno, Attorney General (Dec. 19, 1997) (asking "how long [Attorney General Reno] intend[s] to have Mr. Lee serve in. [sic] an acting capacity" and requesting a written opinion concerning the applicability of the Vacancies Act to Lee's appointment or reasons that the Act is inapplicable) (on file with the Duke Law Journal); see also David Stout, Senator Asks How Long Rights Choice Will Remain, N.Y. TIMES, Dec. 20, 1997, at A6.

37. E.g., Sean Scully, Bid to Reform Vacancies Act up in Air, WASH. TimES, Sept. 29, 1998, at A6 ("Democratic opponents of the bill don't deny that presidents routinely ignore the Va- 
mony to Congress ${ }^{38}$ and a letter to Senator Hatch, ${ }^{39}$ the Administration responded that the Justice Department's enabling statute supersedes the Vacancies Act and subjects acting appointees to "no precise limit on the time during which an official may carry out the duties of a vacant Senate-confirmed office." 40

Frustrated by President Clinton's "blatant disregard of the Judiciary Committee's decision not to support his controversial choice" of Lee and intent on "preserv[ing] and strengthen[ing] the advice and consent role of the Senate," Senators Robert Byrd (D-WV), Fred Thompson (R-TN), Strom Thurmond (R-SC), and Senate Majority Leader Trent Lott (R-MS) proposed the Federal Vacancies Reform Act of 1998 in June. ${ }^{41}$ The White House responded by threatening to veto the Act unless the Senate amended it in three substantive ways and stopped holding nominations "'hostage' for reasons totally unrelated to a nominee's qualifications." sions, the sponsoring senators reintroduced the Act for full Senate consideration in September 1998, but were unable to marshal the necessary votes to stop debate and force a vote. ${ }^{43}$ The failure to end debate was attributed to the Democrats' desire that the Act require

cancies Act...."); The Vacancy Act Fight, WASH. Post, Dec. 29, 1997, at A16 (referring to the Vacancies Act as an "obscure statute"); Vacant Government, WALL. ST. J., Mar. 30, 1998, at A18 ("Clinton aids privately dismiss the ... Vacancies Act as burdensome and obscure ....").

38. Oversight of the Implementation of the Vacancies Act, Hearing Before the Senate Comm. on Governmental Affairs, Mar. 18, 1998 (Statement of Joseph N. Onek, Principal Deputy Associate Attorney General, Department of Justice, and Daniel Koffsky, Special Counsel, Office of Legal Counsel), available at 1998 WL 8993549 [hereinafter Onek Statement] (on file with the Duke Law Journal).

39. Letter from Andrew Fois, Assistant Attorney General, Office of Legislative Affairs, to Orrin G. Hatch, Chairman, Senate Judiciary Committee (Jan. 14, 1998) (on file with the Duke Law Journal).

40. Onek Statement, supra note 38, at 9-10.

41. 144 CONG. REC. S6405-06, *S6416 (June 16, 1998) (statement of Sen. Thurmond); see also 144 CONG. REC. S12,810-06, S12,824 (Oct. 21, 1998) (statement of Sen. Byrd) ("It is my hope that this legislation, which makes several substantive changes to the current Vacancies Act, will protect this vital constitutional 'safeguard' by bringing to an end a quarter century of obfuscation, bureaucratic intransigence, and outright circumvention.").

42. Letter from Erskine Bowles, White House Chief of Staff, to Trent Lott, Senate Majority Leader (July 28, 1998) (demanding that the Senate (1) loosen the Act's restrictions on who can serve in an "acting" capacity, (2) add a safety valve to avert possible interference with duties critical to national security, criminal law enforcement, public health and safety, or the stability of financial markets, and (3) increase the Act's allotted time for new administrations to fill positions) (on file with the Duke Law Journal).

43. Stephen Green, Senate Fails to Force Out Appointee, SAn DiEgo Union \& TRIB., Sept. 29, 1998, at A5 (reporting that the Republican-controlled Senate fell seven votes short of the sixty votes required to end a Democratic filibuster of the Act). 
the Senate to consider presidential nominees more quickly and fairly. ${ }^{44}$

On October 21, 1998, however, the Act reappeared in an amended form. ${ }^{45}$ Retaining its essentials but modified to address some of the earlier concerns of Senate Democrats and the Administration, Congress passed the Act as a rider to the Omnibus Consolidated and Emergency Supplemental Appropriations Act of 1999. ${ }^{46}$ Presented with the all-encompassing Omnibus Act only two weeks before the 1998 congressional election and one day after the House Judiciary Committee announced its intention to conduct impeachment hearings, President Clinton signed into law the Omnibus Act, and with it the Federal Vacancies Reform Act of $1998 .^{47}$

\footnotetext{
44. Id. Democrats' opposition to the version of the Federal Vacancies Reform Act of 1998 proposed in September 1998 also may have been motivated by the Clinton administration's renewal of its objections to the Act just four days before the vote. Statement of Administration Policy from Office of Management and Budget to the Senate (Sept. 24, 1998), http://www.whitehouse.gov/OMB/legislative/sap/1998/S2176-s.html (reiterating that President Clinton's senior advisers will recommend that he veto the Act "if the bill is not amended to address the Administration's concerns ... fully described in the attached Erskine Bowles 7/28/98 letter to the Senate") (on file with the Duke Law Journal).

45. 144 Cong. REC. S12,810-06, *S12,824 (statement of Sen. Byrd) (Oct. 21, 1998) ("Mr. President, because I am an original sponsor of the Federal Vacancies Reform Act, and because the Act as it is being enacted differs somewhat from the bill reported to the Senate by the Committee on Governmental Affairs on July 15, 1998, (S. Rpt. 105-250), I wish to offer my perspective ....").

46. Id. at *S12,822 (statement of Act co-sponsor Sen. Thompson) (Oct. 21, 1998) ("Mr. President, I am pleased that the essentials of [the Federal Vacancies Reform Act of 1998] have been incorporated into the Omnibus Appropriations bill...."); Bill Summary and Status for the 105th Congress-H.R. 4328 (Omnibus Consolidated and Emergency Supplemental Appropriations Act of 1999), available at http://thomas.loc.gov (on file with the Duke Law Journal).

47. 5 U.S.C. $\S \S 3345-3349$ d (Supp. V 1999). To date, neither President Clinton nor any member of his Administration has explained why the President signed into law an Act to which he twice objected and which significantly and unconstitutionally upsets the balance of power on federal appointments. The timing of the midterm congressional election and Congress's impeachment hearings are plausible explanations.

Because the Omnibus Act authorized substantial additional appropriations for numerous causes that Clinton supported (e.g., education and job training, welfare-to-work programs, health care, environmental protection, law and civil rights enforcement, and hurricane relief to farmers), Clinton likely thought it wiser to sign the bill and publicly note its objectionable provisions than to risk losing time-sensitive public support for himself and Democratic candidates by vetoing the bill. In his signing statement, Clinton did publicly object to some parts of the Act but did not mention the Federal Vacancies Reform Act of 1998. In light of the bill's timing, he may have deliberately opted to focus his remarks on issues directly relevant to voters rather than on a longstanding, seemingly "inside the Beltway" interbranch conflict. See generally Statement by President William J. Clinton upon Signing H.R. 4328, 34 Weekly Comp. Pres. Doc. 2108 (Nov. 2, 1998), 1998 U.S.C.C.A.N. 576 (championing the bill as a "significant step forward for America" but objecting to its ban on voluntary national student achievement tests, inadequate fund-
} 


\section{THE FEDERAL VACANCIES REFORM ACT OF 1998}

The Federal Vacancies Reform Act of 1998 replaces all prior Vacancies Acts and rewrites the law governing the President's exercise of the nomination and appointment powers in six significant ways. First, the Act states that it is the exclusive statutory means for temporarily filling vacant advice and consent positions in the executive branch, $^{48}$ unless Congress explicitly legislates otherwise. ${ }^{49}$ No longer can agencies use their enabling statutes as an alternative basis for or superseding means of filling vacancies. ${ }^{50}$ Now, the President is restricted to the means enumerated in the Act to appoint temporarily all executive branch officers whose appointment requires Senate confirmation, except for a few specified officers. ${ }^{51}$

Second, the Act creates a new incentive for prompt submission of nominations. During lengthy recesses or adjournments, the President's submission of a written notification of intent to nominate a named person to a designated vacant position when the Senate reconvenes permits that person to occupy that position until the Senate acts on the nomination. ${ }^{52}$ When the Senate reconvenes, it automati-

ing for air traffic control operations, and constraints on the President's constitutional authority to conduct foreign affairs and to recommend and use federal appropriations).

In addition, Clinton may have signed the Act because the bill-signing provided an opportunity to shift the public's attention away from impeachment hearings, to demonstrate his commitment to continue to carry out his presidential duties, and to provide a positive legislative achievement on which Democratic candidates could campaign while their party's President was being impeached. On the impeachment hearings, see Juliet Eilperin, Mid-November Hearings on Impeachment Planned; Hyde Sets Meeting on Ground Rules, WASH. POST, Oct. 21, 1998, at A02 (reporting that House Judiciary Committee Chairman Henry J. Hyde (R-IL) announced on October 20 that impeachment hearings would begin "shortly after the election").

48. 5 U.S.C. $\$ 3347$ (a) (Supp. V 1999).

49. According to the Act, Congress can "state otherwise" either by expressly authorizing the President, a court, or an executive agency head to fill a vacancy temporarily, or by designating by law an officer or employee to assume a particular vacant office temporarily. $I d$.

50. Id. $\S 3347$ (b). Since 1973, the Department of Justice has claimed that 28 U.S.C. $\S 509$ and $\S 510$, which vest all functions of that agency in the Attorney General and allow her to delegate responsibility for carrying out those functions, provide an alternative, though equally legitimate, basis for temporarily filling vacant advice and consent positions. See supra notes 2640 and accompanying text.

51. The Act does not apply to the temporary appointment of "holdovers," officers who are statutorily authorized to continue to serve in office after their term of years expires until a successor is appointed or a statutorily specified amount of time passes. 5 U.S.C. $§ 3349 \mathrm{~b}$ (Supp. V 1999). Nor does the Act apply to the temporary appointment of officers who serve on independent multiple-member boards or commissions, to commissioners of the Federal Energy Regulatory Commission, to members of the Surface Transportation Board, or to any judge of any court created under Article I of the Constitution. Id. § 3349c.

52. $\quad I d . \S 3349 \mathrm{~d}(\mathrm{a})$. 
cally treats the President's written notification as it would treat an official nomination. ${ }^{53}$ If the President does not actually submit the nomination within two days after the recess or adjournment ends, however, the Senate treats the nomination as withdrawn. ${ }^{54}$

Third, the Act limits the President's choice of temporary appointees and their terms. When an officer dies, resigns, or is otherwise unable to perform assigned duties (e.g., as a result of sickness, absence, or expiration of his term), the Act limits the President's exercise of the temporary appointment power to the following choices: (1) the Senate-confirmed first assistant to the vacant office; (2) a Senateconfirmed officer who currently works in an executive agency; or (3) a career civil servant, paid at or above the GS-15 rate, who has worked in the agency in which the vacancy exists for at least 90 of the past 365 days. $^{55}$ The Act bars the President from temporarily appointing any person who has been nominated to fill the vacant position but has not served as first assistant to that position for at least 90 of the past 365 days. ${ }^{56}$ Moreover, the Act strictly limits all temporary appointees' terms of service to 210 days from the date that the position became vacant. ${ }^{57}$ If, however, the President submits to the Senate a first or second nomination to fill the vacant position, the temporary appointee may continue to serve until 210 days after the Senate rejects or returns the nomination or the President withdraws it. ${ }^{58}$

Fourth, the Act contains a new enforcement mechanism that punishes statutory noncompliance. If the President fails to comply with the Act, then the vacant office must remain vacant, ${ }^{59}$ and no one except the agency head may carry out the duties that are assigned by statute or regulation solely to that office. ${ }^{60}$ Any actions taken by an official not temporarily appointed in compliance with the Act have no effect and cannot be ratified in the future, except by an act of Congress. ${ }^{61}$ In other words, if the President fails to nominate a person to a vacant position within 210 days and exhausts the temporary appoint-

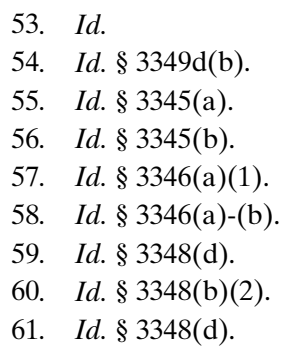


ment options enumerated in the Act, ${ }^{62}$ the President forfeits his temporary appointment power and must submit a nomination or use the recess appointment power to fill the vacant position. ${ }^{63}$

Fifth, the Act requires that the executive branch fully disclose vacancies-related information to Congress and the Comptroller General. ${ }^{64}$ In particular, each executive agency head must "immediately" report to the House, Senate, and Comptroller General the following information: the title of any vacant position; ${ }^{65}$ the name of the acting officer serving in that position and the date her service began; ${ }^{66}$ the name of any person nominated to fill the vacancy and the date of her nomination; ${ }^{67}$ and the date of any rejection, withdrawal, or return of a nomination. $^{68}$ If the Comptroller General determines that an acting officer has exceeded the authorized term of 210 days plus any applicable exceptions, the Comptroller General must report that determination to specified House and Senate Committees, the President, and the Office of Personnel Management..$^{69}$

Sixth, the Act makes special provision for vacancies that occur during presidential transitions. For any vacancy that exists during the first two months after inauguration day, the new President has 90 days in addition to the regular 210 days (300 total) to submit a nomination. ${ }^{70}$ In other words, a new President can temporarily appoint a person to act in any such position for as many as the first 300 days of his first term, plus any time during which the Senate is in recess or is adjourned. Moreover, if the President fails to nominate a person to fill a vacant position within those 300 -plus days or exhausts the available options for temporary appointment under the Act, then the President must leave the position vacant until he submits a nomina-

62. Id. $\S 3345$ (detailing the procedures for a President's selection of temporary officers to fill vacant executive agency positions).

63. Id. $\S 3348$ (c). Part (e) of $\S 3348$ also specifies that it does not apply to the General Counsels of the National Labor Relations Board or Federal Labor Relations Authority, confirmed Inspectors General or Chief Financial Officers, or executive branch officers whose duties cannot, by statutory mandate, be assumed by an agency head. Id. $§ 3348(\mathrm{e})$.

64. The Comptroller General of the United States is the head of the General Accounting Office (GAO). UnITED STATES GOVERnMENT MANUAL, 2000-2001, at 46 (2000); see also id. at 49 ("Supporting the Congress is GAO's fundamental responsibility.").

65. 5 U.S.C. $\$ 3349(a)(1)$.

66. Id. § 3349(a)(2).

67. Id. \$ 3349(a)(3).

68. Id. § 3349(a)(4).

69. Id. § 3349(b).

70. Id. $\$ 3349 \mathrm{a}$. 
tion or fills it with a recess appointee. ${ }^{71}$ Any actions taken by an acting official serving in that position have no effect. ${ }^{72}$

\section{CONSTITUTIONAL PROBLEMS}

The Federal Vacancies Reform Act of 1998 suffers from at least four constitutional problems: (1) the Act allows the Senate to confirm or reject people whom the President never officially nominated; (2) the Act gives the Senate an impermissible role in making recess appointments; (3) the Act encroaches on the President's ability to nominate and control subordinate executive officers; and (4) the Act transfers too much of the Senate's power in the appointment process to the President in the year following a presidential transition.

\section{A. Unconstitutional Empowerment of the Senate to Nominate Officers of the United States}

First, the Act allows the Senate to treat a President's written notice of intent to nominate as a nomination, despite the fact that the President has yet to and may never nominate the named individual to an advice and consent position. Such treatment of a President's written notice of intent to nominate violates both the "formalist" and "functionalist" Supreme Court decisions on federal appointment issues.

The "formalist" cases read the Constitution as assigning distinct powers to each branch and delimiting the extent to which the branches may share those powers. ${ }^{73}$ The formalist approach to separation of powers focuses on the logical meaning of the Constitution's text and what is known about the Framers' intent. ${ }^{74}$ The formalist approach tends to disregard other reasons for decision, such as institutional competence, historical developments, and policy implications. ${ }^{75}$ During the twentieth century, the Court used this approach to invalidate three types of statutory provisions: those that conditioned the President's power to remove an executive officer on the consent of

\footnotetext{
71. Id. $\S \S 3346,3349 \mathrm{a}(\mathrm{b})$.

72. Id. § 3348(d).

73. Rebecca L. Brown, Separated Powers and Ordered Liberty, 139 U. PA. L. REV. 1513, 1522-27 (1991).

74. Id.

75. Id.
} 
the Senate, ${ }^{76}$ those that allowed Congress to retain removal power over officers exercising executive functions, ${ }^{77}$ and those that permitted Congress to appoint executive officers. ${ }^{78}$ The core problem with those three statutory provisions was Congress's attempt, at another branch's expense, to aggrandize its power over who occupies a federal executive position. $^{79}$

The Court likely would take a similarly formalist approach in evaluating the Act's constitutionality. The Act allows the Senate to exercise what is plainly executive authority: the discretion to choose who will be officially nominated to an advice and consent position. Since preventing one branch from usurping power constitutionally assigned to another branch was a primary concern of the Framers, formalist analysis is appropriate in determining whether the Act is constitutional.

Such analysis suggests that the Federal Vacancies Reform Act of 1998 is unconstitutional because neither the Constitution's text nor any expressions of the Framers' intent indicates that the Senate should have any role in choosing nominees. The text of Article 2, Section 2 plainly states that the power of nomination is vested in the President, not in the Senate. "The grammatical structure of the clause separates the Senate's review from the President's nomination; the phrase '[b]y and with the Advice and Consent of the Senate' modifies 'appoint,' but is separated from 'nominate." ${ }^{81}$ As the Court has periodically noted, the nomination process is "the sole act of the

76. Myers v. United States, 272 U.S. 52, 109-77 (1926) (relying primarily on discussion from the Constitutional Convention and the First Congress, and on the Constitution's text, to hold that "the power to remove officers appointed by the President and the Senate [is] vested in the President alone").

77. Bowsher v. Synar, 478 U.S. 714, $722-27$ (1986) (using statements from the Constitutional Convention, the First Congress, and the Constitution's text to hold that "congressional control" over an executive officer, exemplified by the power to remove, "is constitutionally impermissible").

78. Buckley v. Valeo, 424 U.S. 1, 118-41 (1975) (quoting various constitutional provisions, including Article II, Section 2, The Federalist Papers, and statements from the Constitutional Convention to stress the importance of separation of powers and to support the invalidation of a law that gave Congress the power to appoint officers who perform executive functions).

79. See, e.g., H. Jefferson Powell \& Jed Rubenfeld, Laying It on the Line: A Dialogue on Line Item Vetoes and Separation of Powers, 47 DukE L.J. 1171, 1206 (1998) ("[I]f Members of Congress were able to give themselves the power to execute, interpret, or adjudicate their own laws, then Congress would have no check on its powers at all.").

80. U.S. CONST. art. II, $\S 2$, cl. 2.

81. Gauch, supra note 13, at 339. Gauch also notes that some proponents of robust Senate review concede that the nomination power belongs exclusively to the President. E.g., Mathias, supra note 15, at 202. 
president" and "completely voluntary." ${ }^{22}$ Although the Senate can curb the President's authority to nominate in numerous ways (e.g., by stipulating the qualifications of appointees to congressionally created offices or act slowly on a President's nomination), it cannot designate whom the President selects to fill a particular office. ${ }^{83}$ Until the President officially nominates a specific person to a specific office, the Senate cannot confirm or reject that person, consider that person withdrawn, or return the nomination to the President.

The Act, however, effectively empowers the Senate unilaterally to make those decisions. When the President submits a written notice of intent to nominate a specific person to a specific office after a recess or adjournment, the Act authorizes the Senate to treat that written notice as an official nomination. ${ }^{84}$ If the President does not then officially nominate the specified person to the specified office within two days of the Senate's next meeting, the Act authorizes the Senate to treat the written notice qua official nomination as withdrawn. ${ }^{85}$ In doing so, the Act has three unconstitutional consequences. It effectively allows the Senate to nominate a person whom the President has yet to and may never nominate. It permits an antagonistic Senate to convene and confirm or reject on the first day back from recess a person whom the President may have intended to nominate but ultimately decided not to nominate to a specified (or any other) advice and consent position. It also facilitates creation of a permanent, though inaccurate, public record in the Executive Proceedings of the Senate indicating that a President nominated and then withdrew a specific person, even though the President may have merely submitted a written notice of intent to nominate and then opted not to proceed.

Such unilateral Senate nomination and confirmation or rejection was clearly rejected by the Framers. The Framers deliberately chose to place the nomination power outside of the Senate for two reasons.

82. Marbury v. Madison, 5 U.S. (1 Cranch) 137, 155 (1803) (emphasis added).

83. United States v. Ferreira, 54 U.S. (13 How.) 39, 50-51 (1852); see also Myers v. United States, 272 U.S. 52, 128 (1926):

It is argued that the denial of the legislative power to regulate removals in some way involves the denial of power to prescribe qualifications for office, or reasonable classification for promotion, and yet that has been often exercised. We see no conflict between the latter power and that of appointment and removal, provided of course that the qualifications do not so limit selection and so trench upon executive choice as to be in effect legislative designation.

84. 5 U.S.C. $\$ 3349$ (d) (Supp. V 1999).

85. $I d$. 
First, as Alexander Hamilton wrote, "[O]ne man of discernment is better fitted to analyze and estimate the peculiar qualities adapted to particular offices than a body of men of equal or perhaps even of superior discernment." ${ }^{" 86}$ Second, as Nathaniel Gorham, the sponsor of the advice and consent system, and other delegates said during the Constitutional Convention, giving that power to a legislative body would result in appointments based on political dealing, patronage, favoritism, large states' domination of the process, or considerations other than a person's proper qualifications. ${ }^{87}$ Since then, Congress's general practice has been to concede that the power of nomination is vested in the President alone and that this power is an essential part of the Constitution's checks and balances system. For the most part, Congress also has conceded that the Senate's confirmation power, even in its most robust form, is a negative power that permits the Senate to "ratify or reject the choice [of the President]" but not to designate who shall fill a particular office or to subject to the Senate's confirmation process persons who have not been nominated. ${ }^{88}$

The "functionalist" approach likewise suggests that the Act is unconstitutional. The functionalist approach reads the Constitution to favor balancing the branches' competing interests to ensure that the branches do not threaten each others' core functions. ${ }^{89}$ The Court used this approach in Morrison v. Olson to uphold a statute delegating the executive function of criminal prosecution to an independent counsel not formally associated with any of the branches. ${ }^{90}$ The Court also used the approach in Mistretta v. United States to uphold Congress's delegation of lawmaking power to the United States Sentencing Commission, at least three of whose members are statutorily required to be judges. ${ }^{91}$

The Act violates the separation of powers doctrine under the functionalist cases because it threatens to infringe upon the core executive function of nominating qualified individuals to advice and consent positions. Central to the successful fulfillment of that function is the President's pre-nomination ability to evaluate fully an individual's fitness for a position and chances of confirmation. An important

86. The Federalist No. 76, supra note 14, at 455 (Alexander Hamilton).

87. Gauch, supra note 13, at 344-47; David A. Strauss \& Cass R. Sunstein, The Senate, The Constitution, and The Confirmation Process, 101 YALE L. J. 1491, 1496 (1992).

88. The Federalist No. 66, at 405 (Alexander Hamilton) (Clinton Rossiter ed., 1961).

89. SHANE \& BRUFF, supra note 10 , at 386 n.2.

90. 487 U.S. 654, 693-95 (1987).

91. 488 U.S. 361, 412 (1988). 
tool in that respect is the written notice of intent to nominate, which helps the President to assess a potential nominee's chances of confirmation further without exposing the person or the President's judgment to the unnecessary stigma that could result from formal Senate disapproval of an official nomination. ${ }^{92}$

The current Act, though, would force the President to choose among the following unpalatable courses of action: (1) submit a notice of intent and risk the stigma of Senate hearings and possible rejection; (2) forgo unofficial notification and assume the political risks that accompany an official nomination; or (3) possibly forgo nomination of a nominee altogether. In any of these cases, the Act would impede the President's ability to evaluate fully a potential nominee's fitness and chances, and thereby could weaken the core executive function of nominating qualified individuals to advice and consent positions.

\section{B. Unconstitutional Interference with the President's Authority to Make Recess Appointments}

The second constitutional flaw in the Federal Vacancies Reform Act of 1998 is that it illegitimately interferes with the President's exercise of constitutional authority to make recess appointments. Again, the formalist and functionalist approaches are instructive.

A formalist likely would invalidate the Act because it violates Article II, Section 2, which authorizes the President "to fill up all Vacancies that may happen during the Recess of the Senate." ${ }^{93}$ The Appointments Clause does not give the Senate a role in that process. ${ }^{94}$ The Framers adopted the Clause "without a dissenting vote and with virtually no record to fix intent and scope." ${ }^{95}$ The Department of Jus-

\footnotetext{
92. Paul Charles Light, A Survivor's Guide for Presidential Nominees 35 (2000):

If you have been selected for a high-profile job, or a job that has been vacant for a while and prompted stories about internal disarray within the administration, the White House may have already announced the president's intent to nominate you. . . . The White House Press Office will put out a three- or four-paragraph news release announcing the president's intention to nominate you and detailing your work history, where you went to college and what the position entails.

See also THE Federalist No. 76, supra note 14, at 457 (Alexander Hamilton) (predicting that the Senate's "dissent might cast a kind of stigma upon the individual rejected and might have the appearance of a reflection upon the judgment of the Chief Magistrate").

93. U.S. CONST. art. II, $\S 2$, cl. 3 .

94. Id.

95. FISHER, supra note 11, at 38.
} 
tice has long interpreted the Clause broadly to mean that the President may use the recess appointment power to fill vacancies that occur while the Senate is in session and not solely while it is in recess. ${ }^{96}$ Moreover, the only published judicial opinion referring to this power recognizes that the President may have inherent constitutional authority to make interim appointments. ${ }^{97}$

The Act violates this clear and total vesting of the recess appointment power in the President by giving Congress a role in making recess appointments. Specifically, the Act states that the President may not use the recess appointment power to appoint to an advice and consent position anyone who does not meet the time and eligibility requirements that Congress set out in the Act. ${ }^{98}$ The Act also voids the actions of any acting officer who fails to meet those requirements unless Congress expressly says otherwise. ${ }^{99}$ Moreover, the Act purports to override the President's recess appointment power altogether if the President fails to comply with the Act and exhausts all options available under it. ${ }^{100}$

Proponents of greater congressional power might counter that Congress needs to be able to set limits on the President's recess appointment power lest the President use that power to circumvent the constitutional requirement of Senate consent. ${ }^{101}$ That argument, however, tilts the balance of power too far in favor of the Senate. An example illustrates this shortcoming. Suppose that the Senate decides informally that it will reject any nominee who has actively participated in a partisan political campaign. Nothing in the Constitution

96. Id. at $38 \mathrm{n} .61$ (listing numerous Justice Department opinions supporting the proposition that recess appointments can be made while the Senate is in session).

97. Williams v. Phillips, 482 F.2d 669, 670 (D.C. Cir. 1973) (per curiam) (noting that " $[\mathrm{i}] \mathrm{t}$ could be argued that ... the President [has] an implied power, in the absence of limiting legislation ... to appoint an acting director for a reasonable period of time before submitting the nomination of a new director to the Senate").

98. 5 U.S.C. $\$ \S 3345-3346$ (Supp. V 1999) (detailing the time and eligibility requirements regarding the appointment of acting officers); supra notes 55-63 and accompanying text.

99. 5 U.S.C. $§ 3348$ (d) ("An action taken by any person who [does not meet the time and eligibility requirements] ... shall have no force or effect.").

100. Id. $\S 3348$ (a) ("Unless an officer or employee is performing the functions and duties [of the vacant office] in accordance with sections 3345,3346 , and $3347 \ldots$ the office shall remain vacant....").

101. Oversight of the Implementation of the Vacancies Act: Hearing Before the Senate Comm. on Governmental Affairs, Mar. 18, 1998 (Statement of Morton Rosenberg, Specialist in American Public Law, Congressional Research Service), available at 1998 WL 8993467 (on file with the Duke Law Journal). 
appears to prevent the Senate from doing so. ${ }^{102}$ But such an action by the Senate might prevent the President from carrying out the President's duty, under Article II, Section 3, to "take Care that the Laws be faithfully executed." dent's recess appointment power to Senate restrictions might significantly limit the President's ability to carry out his constitutionally authorized duty to "take care." The Framers could not have intended that result, so they probably also did not intend that Congress should limit the President's exercise of the recess appointment power. Because the Act's multiple time and eligibility qualifications for recess appointees limit the President's use of the recess appointment power, ${ }^{104}$ it is unconstitutional.

A functionalist, too, likely would invalidate the Act because it circumscribes the President's power to make recess appointments, thereby impairing the President's ability to accomplish constitutionally assigned functions. Though the text of the Constitution plainly vests the authority to make recess appointments in the President, ${ }^{105}$ several modern cases reject a requirement of absolute independence and make clear that mere interference with one branch's freedom of action does not violate the separation of powers doctrine. ${ }^{106}$ Indeed, since 1863 Congress has passed numerous statutory restrictions on the President's recess appointment power in order to prevent an "ambitious, corrupt or tyrannical executive" ${ }^{107}$ from using that power to undermine the Senate's authority to confirm appointments. ${ }^{108}$

102. Although the Supreme Court has stated that Congress may not enact legislation providing that "no Republican... shall be appointed to federal office," it has also strongly intimated that Congress could refuse to confirm nominees who engage in partisan political activities. United Pub. Workers v. Mitchell, 330 U.S. 75, 100 (1947) (finding that the Civil Service Commission could discipline an employee who acted as a ward executive committeeman of a political party).

103. U.S. CONST. art. II, $\S 3$.

104. 5 U.S.C. $\S \S 3345,3346,3348$.

105. U.S. CONST. art. II, § 2, cl. 3 ("The President shall have Power to fill up all Vacancies that may happen during the Recess of the Senate, by granting Commissions which shall expire at the End of their next Session.").

106. E.g., Mistretta v. United States, 488 U.S. 361, 380-82 (1989) (holding that Congress did not violate the separation of powers principle by empowering the President to appoint or remove members of the United States Sentencing Commission); Nixon v. Adm'r of Gen. Servs., 433 U.S. 425, 441-43 (1977) (rejecting former President Nixon's argument that the Presidential Recordings and Materials Act violates the separation of powers principle).

107. FISHER, supra note 11, at 40 (quoting S. REP. NO. 38-80, at 5-6 (1863)).

108. Id. at 26-27, 40 (observing that Congress has leveraged its power of the purse to withhold, pending confirmation, funds to pay the salaries of acting officials whom the President appointed during a recess to fill an advice and consent position that was vacant while the Senate 
Nonetheless, the Act is unconstitutional, because it facilitates more congressional interference with the President's core ability to make recess appointments than Mistretta allows. ${ }^{109}$ The Act not only restricts the pool of potential recess and temporary appointees, but also deprives a President who refuses to comply with the Act of the constitutionally given authority to make a recess or temporary appointment to a vacant advice and consent position. The potential implications of those problems are best illustrated by an example.

Suppose that the Secretary of Defense becomes ill, resigns, or dies. Unless the President officially nominates a new Secretary, the Act limits the President's choice of temporary or recess appointees to first assistants, other Senate-confirmed officials, and high-level civil servants who have worked in the agency in which the vacancy occurred for ninety days of the past year. ${ }^{110}$ The President may not, for example, appoint a former Secretary of Defense who has retired or now works in the private sector. Now suppose that the President appoints an acting Secretary from that congressionally restricted pool of potential replacements. During the ensuing 210 days, the President searches for someone whom he can officially nominate but is repeatedly distracted by America's entanglement in an international conflict. At this point, the acting Secretary of Defense has exceeded the Act's 210-day limit and must vacate the position. ${ }^{111}$ The Act voids any subsequent action taken by the acting Secretary, ${ }^{112}$ such as executing a presidential order to deploy troops to the region of conflict. Until the President either officially nominates a new Secretary or waits until the next Senate recess to appoint another acting Secretary, the Act requires that the cabinet post remain vacant and bars the President from using his constitutionally authorized recess appointment power to fill that vacancy. ${ }^{113}$ In doing so, the Act inadequately recognizes the

\footnotetext{
was in session; that Congress has used its power of advice and consent aggressively to condition its consent upon the President's nomination of an appointee who meets a long list of qualifications stipulated by Congress; and that senators have wielded their leadership positions and influence over legislative proposals by the President to bully the President into or to block him from appointing particular candidates).

109. See supra notes 105-08 and accompanying text.

110. 5 U.S.C. $\$ 3345$ (a) (Supp. V 1999).

111. Id. $\$ 3346$.

112. Id. § 3348 .

113. Because $\S 3347$ (a) establishes the Act as "the exclusive means" for temporarily authorizing an acting official to perform the functions of a vacant advice and consent position, the Act appears to bar even a President's use of an executive order to set forth an automatic line
} 
difficulties that these types of restrictions may impose on a President's ability to execute faithfully his constitutional duties to serve as commander-in-chief and to protect and defend the United States. ${ }^{114}$

\section{Unconstitutional Encroachment on the President's Authority to Nominate and Control Subordinate Executive Officers}

A third constitutional problem with the Act is that its reporting requirement facilitates congressional encroachment on the President's long-recognized prerogative to nominate and control subordinate executive officers. Simple statutory reporting requirements are constitutional as a general matter. ${ }^{115}$ Nonetheless, past administrations have successfully challenged statutory provisions that require an executive agency to report specified information directly to Congress, on the grounds that the provisions prevent "the Executive Branch from accomplishing its constitutionally assigned functions." ${ }^{116}$ The Act's reporting requirement is just such a provision: it obligates each agency head to report any vacancy, temporary appointment, or official nomination directly and immediately to Congress, without clearance from the President. ${ }^{117}$

Suppose that the Act imposed its reporting requirement not on the head of each executive agency, but on the President alone. Such a provision would be constitutional because it would serve the legitimate congressional purpose of overseeing the activities of the executive branch. Such a provision also would be constitutional because it

of succession to act for an ill, absent, or deceased Secretary of Defense. For an example of such an order, see Exec. Order No. 13,000, 61 Fed. Reg. 18,483 (Apr. 24, 1996).

114. U.S. CONST. art. II, § 2, cl. 1; id. art. II, § 1, cl. 7.

115. 6 Op. Att'y Gen. 326, 344 (1854) (explaining that "Congress may at all times call on [the executive departments] for information or explanation in matters of official duty"); see also INS v. Chadha, 462 U.S. 919, 955 n.19 (1983) (describing means of congressional control over its "administrative creatures," such as "formal reporting requirements"); The Constitutional Separation of Powers Between the President and Congress, Op. Off. Legal Counsel § II.D.2 (May 7, 1996) ("Simple reporting requirements ... are clearly constitutional as a general matter."), available at 1996 WL 876050 [hereinafter Constitutional Separation of Powers]. Despite the general constitutionality of simple statutory reporting requirements, specific instances of congressional oversight of executive actions still might be objectionable on policy and executive privilege grounds. E.g., 1 Op. Att'y Gen. 242, 243 (1820) (advising Henry Clay, then House Speaker and later Senator, Secretary of State, and three-time presidential candidate, that rendering legal advice to the House not only would "enlarg[e] the sphere of [the Attorney General's] official duties beyond that which is prescribed by law," but also would be "incalculably dangerous" to the nation's republican form of government).

116. E.g., Nixon v. Adm'r of Gen. Servs., 433 U.S. 425, 443 (1977).

117. 5 U.S.C. $\$ 3349$. 
would not erode any executive privilege, since information about federal vacancies and the personnel temporarily filling them is not privileged.

Now suppose that the Act directed each agency head to submit vacancies-related information to the President for review before forwarding it to Congress. For the same reasons, this reporting requirement would be constitutional, though its bureaucratic nature might raise concerns about interference with the President's central constitutional obligations. ${ }^{118}$

Finally, consider the Act in its actual form. The Act directs each agency head to submit information about vacancies and nominations directly and immediately to Congress, without presidential clearance. ${ }^{119}$ That requirement appears to be unconstitutional because it "interrupt[s] the lines of responsibility within the executive branch and interfere[s] with a presidential prerogative to control the presentation of the executive branch's views to Congress." ${ }^{120}$ Such interference could result in awkward situations for the President and may even be an unconstitutional erosion of presidential authority, as the following example illustrates.

Suppose that the Secretary of Commerce dies suddenly. The President wants to announce the Secretary's death and to name a temporary replacement or official nominee very quickly to minimize public fear of economic instability. ${ }^{121}$ In such a situation, the Act would compel the Department of Commerce to report the vacancy caused by the Secretary's death directly and immediately to Congress. While the Department probably would inform the President before it

118. U.S. CONST. art. II, $\S 3$ ("[The President] shall from time to time give to the Congress Information of the State of the Union, and recommend to their Consideration such Measures as he shall judge necessary and expedient... he shall take Care that the Laws be faithfully executed, and shall Commission all the Officers of the United States.").

119. 5 U.S.C. $§ 3349$.

120. Constitutional Separation of Powers, supra note 115, § II.D.2 (citing 6 Op. Off. Legal Counsel 632 (1982); 1 Op. Off. Legal Counsel 16, 17 (1977)); see also Myers v. United States, 272 U.S. 52, 162-63 (1926) (discussing the power of the President to remove inferior officers); Cong. Constr. Corp. v. United States, 314 F.2d 527, 530-32 (Ct. Cl. 1963) (holding that the President must have the authority to review the discretionary executive actions of subordinate officials).

121. President Clinton faced such a situation in April 1996, when Secretary of Commerce Ron Brown was killed along with thirty-four others, including several corporate executives, in a plane crash in Croatia. In appointing U.S. Trade Representative Mickey Kantor to replace Brown, the President noted that "he wanted to fill Brown's position quickly 'to send a signal that we don't intend to miss a beat' in pushing his economic policies." William Neikirk, Clinton Looks for Continuity; He Selects Kantor to Replace Brown, CHI. TRIB., Apr. 13, 1996, at 1. 
informed Congress of this news, it is possible that the Department would report the matter to Congress before the President had sufficient time to manage this politically sensitive situation. As a practical political matter, the Act's reporting requirement could at a minimum undermine the President's ability to manage the executive branch effectively by imposing potentially conflicting duties (i.e., the duties of obedience to the President and disclosure to Congress) upon subordinate executive officers and by limiting the amount of time the President has to plan and execute a strategic response. In this way, the requirement increases congressional leverage over the President and other executive branch officials and thereby risks eroding the Constitution's "'great principle of unity and responsibility in the Executive department.",122

\section{Unconstitutional Power Shift Toward the President Following a Presidential Transition}

The three constitutional problems discussed above focus on ways the Federal Vacancies Reform Act of 1998 unduly interferes with the President's constitutional authority. That is not to say, however, that the Act is free of constitutional problems from Congress's point of view. A fourth constitutional difficulty is that the Act tilts the SenatePresident balance of power dangerously toward almost-unilateral presidential control over federal appointments during the first 300 days of a new President's administration.

The Framers required the President to seek the Senate's consent to his nominations because they feared that the President might appoint individuals based solely on private inclinations and interests, as British monarchs had done. ${ }^{123}$ The Framers thought that requiring the Senate's concurrence "would be an excellent check upon a spirit of favoritism in the President, and would tend greatly to prevent the appointment of unfit characters from State prejudice, from family connection, from personal attachment, or from a view to popularity." ${ }^{24}$ Still, the Framers anticipated that Senate consent would be relatively routine, because the President's concern for reputation and reelection would make him "ashamed and afraid" to appoint undeserving can-

122. Myers, 272 U.S. at 131 (quoting James Madison).

123. FISHER, supra note 11, at 22-23 (describing the Framers' rejection of the British model).

124. The Federalist No. 76, supra note 14, at 457 (Alexander Hamilton). 
didates "possessing the necessary insignificance and pliancy to render them the obsequious instruments of his pleasure." 125

The Act, however, facilitates presidential appointments based on patronage and potential for "pliancy" by effectively giving a newly inaugurated President a "blank check" for appointments during the first 300 days of his first term. ${ }^{126}$ The Act authorizes a newly elected President to appoint acting officers to every advice and consent position in the executive branch for up to 300 days after either inauguration day or the date on which the vacancy occurred, whichever is later. ${ }^{127}$ As long as the President nominates a person to each of those offices by the 300th day, the President will not lose the temporary appointment power. ${ }^{128}$ In other words, the Act effectively empowers a new President to staff and run the executive branch for almost an entire year without subjecting any acting appointees to confirmation. Because the Act permits newly elected presidents to engage independently in precisely the kind of favoritism the Framers sought to prevent, it is unconstitutional.

Proponents of the Act might counter that the Act does not free the President of accountability for appointments made during the first year in office; it merely suspends the Senate's exercise of its consent power until the 300th day of a new President's first term. That argument, however, has two flaws. One flaw is that this counter-argument actually strengthens a President's claim that Congress cannot in any way condition a President's temporary appointment power. In creating a 300-day window for initial submission of nominations to the Senate, the Act implies that a President may, for 300 days, make temporary appointments that are not subject to Senate confirmation. A 300 -day period is a relatively long time in political life, and there is no 300-day period during which the Senate is not in session. The Act thus ironically encourages the President not to take seriously the constitutional obligation to submit nominations promptly to the Senate for confirmation. Should the Senate charge the President with failure to submit any nominations before the 300 -day period expires, the President can just point to the language of the Act and argue that he is still within the 300-day period that Congress itself authorized. In this way, the Act converts the President's obligation to heed the Ap-

125. Id. at 458 .

126. 5 U.S.C. $\$ 3349$ a (Supp. V 1999).

127. Id. $\S 3349 \mathrm{a}(\mathrm{b})$.

128. Id. $\S 3348$. 
pointments Clause's advice and consent requirement into an obligation merely not to appoint acting officials for more than 299 days before officially nominating someone to a given advice and consent post. That result, if not unconstitutional, is at least highly undesirable to the Senate.

A second flaw is that suspending the Constitution's consent requirement until the 300th day of a new President's first term imprudently, if not unconstitutionally, expands executive branch powers at the expense of the legislative branch. Political scientists have observed that a President's power to appoint is particularly important during the first few months of the first term. ${ }^{129}$ Made toward the end of the peak period of public interest that accompanies national elections, initial appointments possess an inherent symbolism that a President may use in four powerful ways: "[1] to lay the groundwork for political relationships that will directly affect the future success of his administration, [2] to reward those who have supported him in the past, [3] to broaden his base of support within his own party, with organized interest groups, and in the Congress," and [4] to cement his role as the executive branch's "central creative and directive force." 130 Allocation of that much unbridled power to a single person already inclined to draw power to himself (as freeing the President of accountability for appointments made during the first 300 days in office does) not only is unwise, but also is precisely what the Framers sought to avoid by requiring the Senate's consent. ${ }^{131}$ For that reason, the constitutionality of the Act's provisions for newly elected presidents remains in doubt.

\section{POSSIBLE RESPONSES}

The constitutional barriers to a statutorily delimited appointment process that meets the needs and interests of the executive and legislative branches leave three avenues for those determined to prevent the President from circumventing the Senate's confirmation prerogative. One route, though certainly the most difficult in practice, is to amend Article II, Section 2 to authorize explicitly a greater Senate role in the nomination and appointment processes. ${ }^{132}$ A second option

129. E.g., G. Calvin Mackenzie, The Politics of Presidential Appointments 6 (1981).

130. Id. at 5-9.

131. See supra notes $16-25$ and accompanying text.

132. The author is not aware of any current proposal to amend the appointments-related 
is to modify the Act so that it properly respects the allocation of federal appointment authority that the Framers intended and enshrined in the Appointments Clause. For the reasons discussed in this Note, ${ }^{133}$ such modifications would necessarily delete the provision that empowers the Senate to nominate and confirm or reject individuals who have not been nominated by the President, ${ }^{134}$ reassign the monitoring and reporting requirements from the executive agency heads to the President, and reduce (if not eliminate) the time period the Act gives to a newly inaugurated President. ${ }^{135}$ Finally, a third possibility is to repeal the Act and relegate the Senate to using only its enumerated powers of confirmation and of the purse, or its informal power to horse-trade with the President, in a manner that respects the Constitution's allocation of appointment authority.

\section{CONCLUSION}

Since the ratification of the Constitution, the appointment power enumerated in Article II, Section 2 of the Constitution has operated in "a framework of studied ambiguity, its limits established for the most part not by court decisions but by imaginative accommodations between the executive and legislative branches." ${ }^{136}$ Though much deference has been given to the President's exercise of the power to nominate and to make recess and temporary appointments, Congress has periodically "police[d] the borders of th[at] power by imposing statutory constraints and conditions." 137 The Federal Vacancies Reform Act of 1998 represents Congress's most recent attempt to do so. A historic revision of the appointment process, the Act employs several new statutory mechanisms to expand and protect the Senate's interest, at the expense of presidential authority, in preventing the President from evading the Senate's confirmation prerogative. Rather than arriving at the new legislation through a deliberative and collaborative process that included the President, the Department of Justice, and other executive officials, however, Congress hustled the Act through the legislative process and sent it, buried deep in a veto-

\footnotetext{
clauses in Article 2, Section 2.

133. See supra notes 83-92 and accompanying text.

134. 5 U.S.C. $\$ 3345$ (Supp. V 1999).

135. Id. $\$ 3349$ a.

136. FISHER, supra note 11 , at 48.

137. Id.
} 
proof appropriations bill, to a vulnerable President for signing. ${ }^{138}$ As a result, the Act represents a one-sided response to mounting concern about perversions of the federal appointment process. Little effort was made to preserve the delicate balance, shaped by centuries of rules and norms, between the President's need to staff his administration fully and efficiently and the Senate's desire to maintain its power of advice and consent. To ensure that the federal appointment process functions as the Framers intended and as the constitutional separation and balance of power require, both the Senate and Congress as a whole would do well to remember "that the decision as to who will make the decision affects what decisions will be made," and that the Constitution squarely vests that initial decisionmaking power concerning federal appointments in the President. ${ }^{139}$

138. See supra notes 45-47 and accompanying text.

139. John Anthony Maltese, The Presidency and the Judiciary, in THE PRESIDENCY AND THE Political System 507 (Michael Nelson ed., 1994) (quoting Memorandum from Tom Charles Huston, former White House aide, to President Nixon 1 (Mar. 25, 1969)). 